\title{
Simultaneous electrodialytic removal of PAH, PCB, TBT and heavy metals from sediments
}

\author{
Kristine B. Pedersen ${ }^{* a, c}$, Tore Lejon ${ }^{a}$ Pernille E. Jensen ${ }^{b}$ and Lisbeth M. Ottosen ${ }^{b}$ \\ *Corresponding author: e-mail kristine.pedersen@akvaplan.niva.no; tel. +47 92879928; fax.
}

$+4777750301$

${ }^{a}$ Department of Chemistry, University of Troms $\varnothing$ - The Arctic University of Norway, Postbox 6050 Langnes, N-9037 Troms $\varnothing$, Norway.

${ }^{\mathrm{b}}$ Arctic Technology Centre, Department of Civil Engineering, Technical University of Denmark, Building 118, 2800 Lyngby, Denmark

${ }^{\mathrm{c}}$ Present address: Akvaplan-niva AS, High North Research Centre for Climate and the Environment, P.O. Box 6606, Langnes, 9296 Troms $\varnothing$, Norway

\begin{abstract}
Contaminated sediments are remediated in order to protect human health and the environment, with the additional benefit of using the treated sediments for other activities. Common for many polluted sediments is the contamination with several different pollutants, making remediation challenging with the need of different remedial actions for each pollutant. In this study, electrodialytic remediation (EDR) of sediments was found effective for simultaneous removal of heavy metals and organic pollutants for sediments from Arctic regions - Sisimiut in Greenland and Hammerfest in Norway. The influence of sediment properties and experimental settings on the remediation process was studied by employing multivariate analysis. The importance of the variables studied varied with the pollutant and based on these results it was possible to assess removal processes for the different pollutants. Desorption was found to be important for the removal of heavy metals and TBT, while photolysis was significant for removal of PAH, PCB and TBT. In addition, dechlorination was found to be important for the removal of $P C B$. The highest removal efficiencies were found for heavy metals, TBT and PCB (>40\%) and lower removal efficiencies for PAH $(<35 \%)$.

Keywords: Chemometrics, electrokinetics, heavy metals, POPs, TBT
\end{abstract}




\section{Introduction}

The Arctic Council has identified persistent organic pollutants (including polyaromatic hydrocarbons (PAH) and polychlorinated biphenyls (PCB)), $\mathrm{Cd}, \mathrm{Hg}$ and $\mathrm{Pb}$ as priority substances in their Arctic Monitoring and Assessment Programme (AMAP). Accumulation of these compounds in the Arctic environment as well as bioaccumulation in mammals and humans in the Arctic have been observed (Commission, 2008; Hung et al., 2010; Programme, 2003, 2005; Rigét et al., 2010). In addition to these compounds, tributyltin (TBT) and the heavy metals $\mathrm{As}, \mathrm{Cr}, \mathrm{Cu}, \mathrm{Ni}$ and $\mathrm{Zn}$ are included in the national sediment quality criteria of countries represented in the Arctic Council (Agency, 2005; Agency, 2016; Agency), 2007; CCME, 2016).

The choice of remediation technology is based on site-specific conditions, including the sediment properties, pollutant composition, social and economic considerations. In-situ technologies are for instance often only relevant in areas for which future contact with the sediments is minimal and are often based on decreasing the bioavailability of the pollutants by isolation and/or stabilisation (Mulligan et al., 2001; Perelo, 2010). The ex-situ management of dredged sediments involves either disposal on land or at sea; or treatment. When treatment is an option, a first step is often physical separation of the dredged sediment to retrieve the finer fractions, in which the majority of the pollution is bound (Chapman et al., 1998). The subsequent treatment can be roughly divided into physical, biological and/or chemical technologies and include thermal degradation/extraction, biological degradation, chemical oxidation/reduction/separation, electrokinetics, stabilisation/solidification (STSO) and washing (Mulligan et al., 2001; Peng et al., 2009; Perelo, 2010; Sato et al., 2010). However, since most techniques have been developed for removing specific (classes of) pollutants, several methods often have to be employed if aiming at removal of complex mixtures of pollutants. It would thus be an advantage if the same methodology could be employed, irrespective of which type of pollutant is to be removed. In this respect, electrodialytic remediation (EDR) has proven an interesting method.

By applying an electric field to the polluted material and employing ion-exchange membranes to control the transport of ions to/from the electrodes, electrodialytic remediation separates pollutants from solid waste and has proven a good method for removing heavy metals from harbour sediments and soils (Nystroem et al., 2005a; Ottosen et al., 1997). The principles of electrodialytic remediation is to ensure acidification of the polluted material and subsequent desorption and transport of ions (including metals) to the electrode of opposite charge. In the 3-compartment cell design (figure 1), used in this study, acidification occurs due to water splitting at the anion exchange membrane(Ottosen et al., 2000) as well as proton leakage from the cathode compartment (Nystroem et al., 2005a). Transport processes in the sediment under the influence of an electric field include electromigration (transport of ions in solution), electroosmosis (transport of fluid through pores), electrophoresis (transport of charged particles) and diffusion (Acar and Alshawabkeh, 1993). Ions are mainly transported by electromigration (Acar and Alshawabkeh, 1993), hydrophobic pollutants by electroosmosis (Gill et al., 2014; Lohner et al., 2009; Wick, 2009) while microorganisms may be transported via electroosmosis (if weakly charged) and/or electrophoresis (Wick, 2009). 


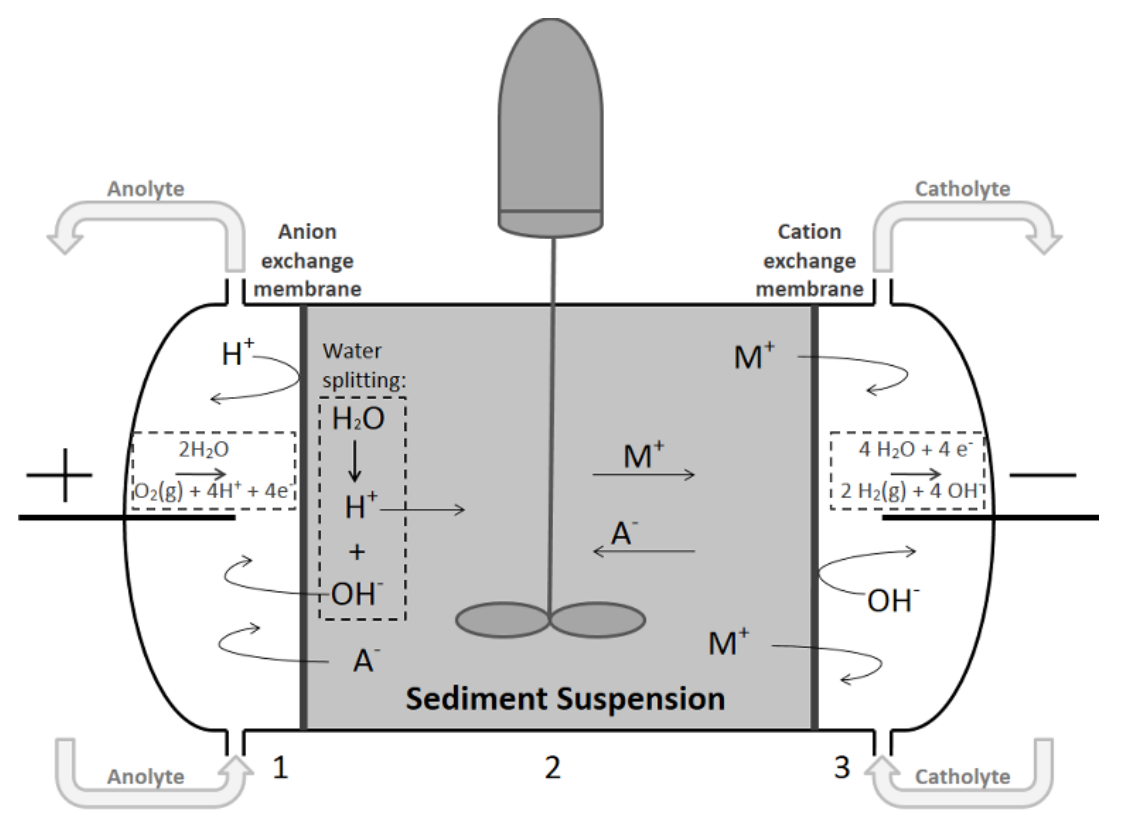

Figure 1: The 3-compartment electrodialytic cell set-up. The principles of electrodialytic remediation is to achieve acidification in the sediment suspension by water splitting at the anion exchange membrane, the immediate transport of hydroxyl ions to the anode compartment and prevention of hydroxyl ions, produced at the cathode, from entering the sediment suspension.

High removal efficiencies of heavy metals during EDR (90\%) have been reported, in some cases achieving final concentrations equivalent to background levels (Nystroem et al., 2005a, b; Pedersen et al., 2015c; Pedersen et al., 2015e; Pedersen et al., 2015f). Removal of organic pollutants by EDR have been conducted in combination with other remediation technologies, e.g. using nano-particles and surfactants to achieve removal efficiencies of PCB from soil of up to 76\% (Gomes et al., 2014). Numerous electrokinetic remediation studies, in which passive membranes are used to separate the polluted material from the electrode compartments, have shown that the removal of PAH and PCB are increased by combining with other technologies, such as bioremediation and chemical oxidation/reduction, rather than applying each technology individually (Colacicco et al., 2010; Gill et al., 2014; Gomes et al., 2013; Yang, 2009). Removal of TBT by EDR or EKR has not been reported, however, applying a high intensity electric field on TBT polluted sediment (electrochemical oxidation) resulted in removal efficiencies of up to $83 \%$ attributed to produced radicals at the electrodes, the technology did however not affect heavy metal concentrations in the sediment (Arevalo et al., 2004).

Applying a stirred, rather than stationary set-up has shown to more efficiently (faster and lower electric energy consumption) remove metals (Ottosen et al., 2012) and the rate of stirring has proven important for the removal of PAH (Lima et al., 2012; Pedersen et al., 2016b). Current density, remediation time, liquid-solid (L/S) ratio are other variables affecting the efficiency (Kirkelund et al., 2009; Nystroem et al., 2005a, b; Nystrøm et al., 2005; Pedersen et al., 2015c; Pedersen et al., 2015e). Preliminary experiments have shown that temperature influences the removal of heavy metals from kaolinite (Ottosen et al., 2008) while any influence of light or temperature on removal of organic contaminants during EDR have not been reported.

Chemometric methods are excellent tools for extracting information from data sets and in EDR has previously been used for identifying the more important experimental variables (Pedersen et al., 
2015c; Pedersen et al., 2015d; Pedersen et al., 2015e; Pedersen et al., 2015f), determining optimal settings (Pedersen et al., 2016a; Pedersen et al., 2015e) and predicting experimental settings for new sediment, based on a database with several sediments (Pedersen et al., 2015e). Chemometrics has also been used for describing pollutant distribution, clustering related to sediment properties and assessing pollution sources (De Luca et al., 2004; Pedersen et al., 2015b).

Hammerfest in Northern Norway and Sisimiut in Greenland are two Arctic locations where heavy metals, PAH, PCB and TBT have been found in harbour sediments (Pedersen et al., 2015b). Since both harbours are ice-free during the winter, sediment remediation is possible throughout the year. It hence appears imperative to develop cost-efficient technologies for remediating sediments tolerating periods of low temperature as well as limited exposure to light. Samples from these locations were therefore chosen for investigation of the applicability of simultaneous electrodialytic remediation. Chemometrics were applied for assessing pollutant composition before/after treatment and identifying the relative influence of the experimental variables (current, time, stirring rate, $\mathrm{L} / \mathrm{S}$ ratio, temperature, light and type of sediment) on the remediation efficiency.

\section{Methods and materials}

\subsection{Sediments}

Sediments were sampled from the top $10 \mathrm{~cm}$ of the seabed adjacent to former shipyard (Sisimiut, Greenland) and adjacent to the previous sewage discharge and outlet of the freshwater lake, Storvatn (Hammerfest, Norway).

\subsection{Analytical}

Major elements were analysed by Inductively Coupled Plasma - Optical Emission Spectroscopy (ICPOES) after digestion (Danish standard DS259). PAH, PCB, THC (ISO/DIS 16703) and TBT were measured by Eurofins, Moss, Norway. Chloride content was measured by ion chromatography. Carbonate content was determined in a Scheibler apparatus, calibrated with $\mathrm{CaCO}_{3}$. Organic content was based on loss of ignition. $\mathrm{pH}(\mathrm{KCl})$ was measured using a radiometric analytical electrode. Grain size distribution was determined after wet sieving (above and below $63 \mu \mathrm{m}$ ).

Desorption tests were made by agitating dried sediment with $\mathrm{HNO}_{3}(0.01 \mathrm{M}-1 \mathrm{M})$ for a week on a horizontal shaker. After settling, $\mathrm{pH}$ was measured in the liquid, sediment suspensions were vacuum filtered through a $45 \mu \mathrm{m}$ filter and the liquid samples were analysed by ICP-OES.

\subsection{EDR experiments}

The electrodialytic cell $(\mathrm{d}=8 \mathrm{~cm}$ ) was manufactured from Plexiglas and consisted of 3 compartments separated by anion exchange membrane 204SZRAB02249C and cation exchange membrane CR67HUYN12116B from lonics (figure 1). The centre compartment $(\mathrm{I}=10 \mathrm{~cm})$ contained the polluted sediments in suspension and electrolyte liquids were circulated in the two adjoining compartments (I $=3.5 \mathrm{~cm}$ ). The electrolytes $\left(\mathrm{NaNO}_{3}, 300 \mathrm{ml}\right.$, continuously adjusted to $\mathrm{pH} 2$ by adding $\mathrm{HNO}_{3}$ ) were circulated via Ismatec reglo pump with a flow rate of $10 \mathrm{ml} / \mathrm{min}$. Platinum coated titanium electrodes were used in each electrolyte compartment and a power supply (Hewlett Packard E3612A) maintained a constant DC current. The sediment suspension was stirred by a CAT R14 motor with a stirrer consisting of plastic flaps $(4 \mathrm{~cm} \times 0.5 \mathrm{~cm})$ fastened to a glass rod. No light conditions in selected 
experiments were conducted by covering the EDR cell in tin foil. Temperature of $4^{\circ} \mathrm{C}$ in electrodialytic cell was ensured by conducting the selected experiments in a fridge.

After the EDR experiments sediments were filtered through a Whatman CAT 1113-320 filter and the metal concentrations in both the suspension liquid and solids were measured. The stirrer, membranes and electrodes were soaked in $\mathrm{HNO}_{3}(5 \mathrm{M})$ overnight and the heavy metal (excluding $\mathrm{Hg}$ ) concentrations in the soaking liquids as well as the electrolyte liquids were measured.

\subsection{Design}

An experimental design was made for testing the comparative influence of the 7 experimental variables. The continuous variables were current density, time after acidification, stirring rate, $L / S$ ratio and temperature. The discrete variables were light/no light and sediment. By assuming that the interaction effects compared to the main effects are negligible, the amount of experiments could be reduced from a complete $2^{7}$ factorial design to a $2^{7-4}$ fractional factorial design consisting of 8 experiments (1-8). In order to ensure that maximum variation in the experimental domain was covered, MODDE7 software was used for the design. A second design was made for assessing variable influence in the Hammerfest sediment based on a $2^{6-3}$ fractional factorial design. By re-using four of the experiments in design 1 (no. 1, 4, 6 and 7), it was only necessary to conduct four more experiments (9-12). 
Table 1: Experimental settings for the EDR experiments.

\begin{tabular}{|c|c|c|c|c|c|c|c|c|}
\hline Experiment & $\begin{array}{l}\text { Current } \\
\text { density }\end{array}$ & $\begin{array}{l}\text { Time after } \\
\text { acidification }\end{array}$ & $\begin{array}{l}\text { Stirring } \\
\text { rate }\end{array}$ & $\begin{array}{l}\text { L/S } \\
\text { ratio }\end{array}$ & Light & Temperature & Sediment & Design \\
\hline & $\mathrm{mA} / \mathrm{cm}^{2}$ & $\mathbf{h}$ & rpm & $\mathrm{mL} / \mathrm{g}$ & & ${ }^{\circ} \mathrm{C}$ & & \\
\hline 1 & 0.2 & 48 & 100 & 2 & Light & 20 & Hammerfest & 1,2 \\
\hline 2 & 1.0 & 48 & 100 & 4 & $\begin{array}{l}\text { No } \\
\text { light }\end{array}$ & 20 & Sisimiut & 1 \\
\hline 3 & 0.2 & 444 & 100 & 4 & Light & 4 & Sisimiut & 1 \\
\hline 4 & 1.0 & 444 & 100 & 2 & $\begin{array}{l}\text { No } \\
\text { light }\end{array}$ & 4 & Hammerfest & 1,2 \\
\hline 5 & 0.2 & 48 & 1300 & 2 & $\begin{array}{l}\text { No } \\
\text { light }\end{array}$ & 4 & Sisimiut & 1 \\
\hline 6 & 1.0 & 48 & 1300 & 4 & Light & 4 & Hammerfest & 1,2 \\
\hline 7 & 0.2 & 444 & 1300 & 4 & $\begin{array}{l}\text { No } \\
\text { light }\end{array}$ & 20 & Hammerfest & 1,2 \\
\hline 8 & 1.0 & 444 & 1300 & 2 & Light & 20 & Sisimiut & 1 \\
\hline 9 & 1.0 & 48 & 100 & 4 & $\begin{array}{l}\text { No } \\
\text { light }\end{array}$ & 20 & Hammerfest & 2 \\
\hline 10 & 0.2 & 444 & 100 & 4 & Light & 4 & Hammerfest & 2 \\
\hline 11 & 0.2 & 48 & 1300 & 2 & $\begin{array}{l}\text { No } \\
\text { light }\end{array}$ & 4 & Hammerfest & 2 \\
\hline 12 & 1.0 & 444 & 1300 & 2 & Light & 20 & Hammerfest & 2 \\
\hline
\end{tabular}

The power consumption in Wh (E) was calculated as:

$\int_{t=0}^{t} E=V I d t$

where $\mathrm{V}$ is the voltage between the electrodes $(\mathrm{V}), \mathrm{I}$ is the current $(\mathrm{A})$ and $\mathrm{t}$ is the remediation time (h).

\subsection{Multivariate modelling}

SimcaP11 software was used for the multivariate modelling. In Principle Component Analysis (PCA) mutually orthogonal vectors, representing independent and uncorrelated variation, are calculated and score plots are obtained by projecting the original data onto these principal component vectors. This results in fewer new descriptors (scores) without loss of systematic information (Carlson and Carlson, 2005a) and similarities/differences in data are visualised. Projections onto latent structures (PLS) models the quantitative relationship between a descriptor matrix, $X$, and a response matrix, $Y$. Object points in the $X$ and $Y$ space are projected onto PLS components with the maximum correlation between the scores of the $X$ and $Y$ matrices, until only noise remains in the $Y$-matrix (Carlson and Carlson, 2005b; Trygg and Wold, 2002; Wold et al., 2001). Advantages of PLS include simultaneous modelling of several responses, coping with collinearity between variables and since it is based on projections, it is possible to have more variables than objects (Carlson and Carlson, 2005c).

PCA was used for evaluating the distribution of PAH components and PCB congeners before and after the EDR experiments and included the concentrations of the different components/congeners in the $\mathrm{X}$-matrix. For the PLS modelling, the X-matrix consisted of the experimental variables and the discrete variables (arbitrarily set to -1 or 1 ). For the comparison of sediments in design 1 , the $Y$ matrix consisted of the fraction of contaminants removed during the EDR treatment. In design 2 , the $Y$ matrix consisted of the final concentrations of the EDR experiments. 
To assess viability and stability of the calculated PLS models, correlation factors, R2Y (the fraction of the Y-matrix explained by the model) and predictive powers, Q2 (an estimate of the reliability of the model calculated by cross-validation) were used. In order to obtain a high predictive power, R2Y should be high. A value of Q2>0.9 indicates a strong model, while a value above 0.5 would be a moderate model. The difference between R2Y and Q2 should be as low as possible and a difference larger than 0.2-0.3 may indicate outliers or the presence of irrelevant variables in the $\mathrm{X}$ block. Variable Importance in the Projection (VIP) values present the absolute importance of each parameter in the model with respect to its correlation to all the responses $(\mathrm{Y})$ and to the projection (X). The VIP values are calculated for each $X$ variable by summing the squares of the PLS loading weights, weighted by the amount of sum of squares explained in each model component. The sum of squares of all VIP's is equal to the number of terms in the model, accordingly the average VIP is equal to 1 . High VIP values $(>1)$ represent high influence of the variable(s) in the model, and VIP values $<0.5$ indicate low influence of the variable(s) on the model. VIP plots were used to assess variable importance in the calculated models. To evaluate the numerical influence of variables, model coefficients were used.

\section{Results and discussion}

\subsection{Sediment characteristics}

The content of carbonate was low and had an equivalent value in both of the studied sediments (table 2). Organic matter may influence the buffer capacity of soil/sediment, hence retarding the acidification during EDR (Acar and Alshawabkeh, 1993) and in addition heavy metals, TBT and organic pollutants are less available for mobilisation/degradation when bound in the organic fraction (Du et al., 2014; Gomes et al., 2013; Matsuzawa et al., 2001). Consequently, the higher content of organic matter may result in lower EDR removal efficiencies in the Hammerfest sediment. The concentrations of chloride and the elements $\mathrm{Al}, \mathrm{Ba}, \mathrm{Fe}, \mathrm{K}, \mathrm{Mn}$ and $\mathrm{Na}$ are higher in the Hammerfest than in the Sisimiut sediment. The content of clay and silt (fraction $<63 \mu \mathrm{m}$ ) is higher in the Sisimiut sediment. For both sediments, more than $50 \%$ of the elements and heavy metals are bound in this fraction.

Table 2: Sediment characteristics and initial concentrations of heavy metals, PAH16, PCB7, TBT and THC compared to sediment quality criteria of OSPAR, Denmark and Norway.

\begin{tabular}{|c|c|c|c|c|c|c|}
\hline Characteristic & Units & $\begin{array}{l}\text { Hammerfest } \\
\text { sediment }\end{array}$ & $\begin{array}{l}\text { Sisimiut } \\
\text { sediment }\end{array}$ & $\begin{array}{l}\text { OSPAR } \\
\text { BAC } \\
\text { (Commission, } \\
\text { 2009) }\end{array}$ & $\begin{array}{l}\text { Danish } \\
\text { SQC } \\
\text { (Agency, } \\
\text { 2005) }\end{array}$ & $\begin{array}{l}\text { Norwegian } \\
\text { SQC (1) } \\
\text { (Agency), } \\
\text { 2007) }\end{array}$ \\
\hline Carbonate & $\%$ & $0.7 \pm 0.2$ & $0.7 \pm 0.1$ & & & \\
\hline Organic matter & $\%$ & $14.8 \pm 1.8$ & $8.5 \pm 0.5$ & & & \\
\hline $\mathrm{pH}$ & & $7.0 \pm 0.1$ & $7.0 \pm 0.0$ & & & \\
\hline Grain size $<63 \mu \mathrm{m}$ & $\%$ & 41 & 60 & & & \\
\hline Chloride & \multirow{8}{*}{$\mathrm{mg} / \mathrm{kg}$} & $14100 \pm 485$ & $6240 \pm 1100$ & & & \\
\hline $\mathrm{Al}$ & & $7100 \pm 710$ & $6800 \pm 410$ & & & \\
\hline $\mathrm{Ba}$ & & $220 \pm 10$ & $150 \pm 10$ & & & \\
\hline $\mathrm{Ca}$ & & $7630 \pm 1350$ & $6900 \pm 930$ & & & \\
\hline $\mathrm{Fe}$ & & $20880 \pm 910$ & $19100 \pm 1400$ & & & \\
\hline $\mathrm{K}$ & & $3140 \pm 710$ & $2800 \pm 230$ & & & \\
\hline $\mathrm{Mg}$ & & $5420 \pm 230$ & $5800 \pm 470$ & & & \\
\hline $\mathrm{Mn}$ & & $140 \pm 4$ & $129 \pm 4$ & & & \\
\hline
\end{tabular}




\begin{tabular}{|c|c|c|c|c|c|}
\hline $\mathrm{Na}$ & $11800 \pm 1800$ & $8700 \pm 420$ & & & \\
\hline $\mathrm{V}$ & $56 \pm 2$ & $62 \pm 3$ & & & \\
\hline $\mathrm{Cr}$ & $37 \pm 3$ & $37 \pm 2$ & $81^{*}$ & 50 & 70 \\
\hline $\mathrm{Cu}$ & $139 \pm 16$ & $214 \pm 7$ & $27^{*}$ & 20 & 35 \\
\hline $\mathrm{Ni}$ & $22 \pm 3$ & $21 \pm 2$ & $36^{*}$ & 30 & 30 \\
\hline $\mathrm{Pb}$ & $137 \pm 23$ & $90 \pm 8$ & 38 & 40 & 30 \\
\hline $\mathrm{Zn}$ & $470 \pm 50$ & $408 \pm 60$ & $122 *$ & 130 & 150 \\
\hline Acenaphtene & $0,24 \pm 0,01$ & $0.72 \pm 0.18$ & & & 0.0048 \\
\hline Acenaphtylene & $0.066 \pm 0.026$ & $0.022 \pm 0.001$ & & & 0.0016 \\
\hline Anthracene & $1.6 \pm 0.4$ & $1.3 \pm 0.3$ & 0.005 & & 0.0012 \\
\hline Benzo(a)anthracene & $8.4 \pm 2.1$ & $4.0 \pm 1.0$ & 0.016 & & 0.0036 \\
\hline Benzo(a)pyrene & $4.3 \pm 1.1$ & $2.0 \pm 0.5$ & 0.03 & & 0.006 \\
\hline Benzo(b)flouranthene & $4.1 \pm 1.0$ & $2.1 \pm 0.5$ & & & 0.046 \\
\hline Benzo(k)fluoranthene & $3.9 \pm 1.0$ & $1.9 \pm 0.5$ & & & 0.21 \\
\hline Benzo(ghi)perylene & $2.4 \pm 1.0$ & $2.4 \pm 1.0$ & 0.08 & & 0.018 \\
\hline Chrysene & $7.8 \pm 2.7$ & $4.2 \pm 1.5$ & 0.02 & & 0.0044 \\
\hline Dibenzo(a,h)anthracene & $0.5 \pm 0.2$ & $0.4 \pm 0.2$ & & & 0.012 \\
\hline Fluoranthene & $17 \pm 4.2$ & $6.2 \pm 1.6$ & 0.039 & & 0.008 \\
\hline Fluorene & $0.46 \pm 0.12$ & $0.79 \pm 0.20$ & & & 0.0068 \\
\hline Indeno(1,2,3-cd)pyrene & $2.0 \pm 0.6$ & $2.4 \pm 0.7$ & 0.103 & & 0.020 \\
\hline Naphtalene & $0.17 \pm 0.04$ & $0.44 \pm 0.11$ & 0.008 & & 0.002 \\
\hline Phenanthrene & $4.0 \pm 1.0$ & $4.4 \pm 1.1$ & 0.032 & & 0.0068 \\
\hline Pyrene & $13 \pm 3.3$ & $4.3 \pm 1.1$ & 0.024 & & 0.005 \\
\hline PAH16 total & 70 & 38 & & $3 * *$ & 0.30 \\
\hline PCB7 & $0.55 \pm 0.14$ & $0.18 \pm 0.04$ & 0.001 & 0.02 & 0.005 \\
\hline TBT & $0.11 \pm 0.04$ & $0.59 \pm 0.24$ & $0.00001^{*}$ & 0.007 & 0.001 \\
\hline THC & 1000 & 2600 & & & \\
\hline
\end{tabular}

BAC - Background Assessment Criteria, $90 \%$ probability that the observed mean concentration will be below BAC when the true mean concentration is the background concentration.

SQC - Sediment quality criteria

*OSPAR Environmental Assessment Criteria (EAC) where BAC values are not available.

**Sum of PAH9: Anthracene, benzo(a)anthracene, benzo(ghi)perylene, benzo(a)pyrene, chrysene, fluoranthene, indeno(1,2,3-cd)pyrene, pyrene,

phenanthrene.

The initial concentrations of contaminants are compared to the sediment quality criteria of OSPAR, Denmark and Norway, where available, in table 2 and the listed threshold values are equivalent to background concentrations. The heavy metals $\mathrm{Cu}, \mathrm{Hg}, \mathrm{Pb}$ and $\mathrm{Zn}$ exceed the sediment quality criteria. The concentrations of PAH (16 EPA focus components), PCB (7 congeners) and TBT also exceed the criteria and the pollutant levels are equivalent to hazardous waste as defined by the Norwegian sediment quality criteria (class 5) (Agency), 2007). Based on the initial concentrations, the targeted pollutants in this study were $\mathrm{Cu}, \mathrm{Pb}, \mathrm{Zn}, \mathrm{PAHs}, \mathrm{PCBs}$ and TBT.

\subsection{Influence of sediment properties}

Results of the EDR experiments are summarised in table 3. Similar acidification times and final $\mathrm{pH}$ values were observed for the two sediments when applying the same experimental settings. The energy consumption levels were generally lower for the Sisimiut sediment and may be related to the lower content of organic matter leading to less clogging of the membranes (Ebbers et al., 2015). The lower energy consumption levels observed have to be related to the removal efficiencies in order to evaluate whether reaching the remediation objectives would result in lower energy consumption for EDR of the Sisimiut compared to the Hammerfest sediments. 
Table 3: Summary of results in the EDR experiments.

\begin{tabular}{|c|c|c|c|c|c|c|c|c|c|c|c|c|}
\hline \multirow[b]{2}{*}{ Experiment } & \multicolumn{8}{|c|}{$\begin{array}{c}\text { Hammerfest } \\
\text { sediment }\end{array}$} & \multicolumn{4}{|c|}{$\begin{array}{l}\text { Sisimiut } \\
\text { sediment }\end{array}$} \\
\hline & 1 & 4 & 6 & 7 & 9 & 10 & 11 & 12 & 2 & 3 & 5 & 8 \\
\hline Acidification time (h) & 190 & 80 & 45 & 41 & 41 & 177 & 166 & 74 & 48 & 172 & 137 & 104 \\
\hline Final $\mathrm{pH}$ & 3.3 & 2.3 & 2.9 & 1.6 & 2.8 & 1.9 & 3.7 & 2.2 & 3.3 & 1.9 & 3.5 & 2.0 \\
\hline $\begin{array}{l}\text { Energy consumption } \\
(\mathrm{kWh} / \mathrm{kg} \mathrm{dw})\end{array}$ & 0.04 & 7.6 & 1.6 & 0.17 & 0.58 & 0.94 & 0.04 & 3.3 & 2.2 & 0.66 & 0.03 & 1.7 \\
\hline \multicolumn{13}{|l|}{ Removal efficiencies (\%) } \\
\hline $\mathrm{Cu}$ & 31 & 2.5 & 3.0 & 0 & 54 & 4.2 & 0 & 0 & 0 & 23 & 14 & 43 \\
\hline $\mathrm{Pb}$ & 9.5 & 0 & 37 & 0 & 0 & 17 & 0 & 0 & 0.6 & 0.1 & 28 & 64 \\
\hline $\mathrm{Zn}$ & 73 & 0 & 78 & 16 & 85 & 38 & 55 & 46 & 61 & 56 & 48 & 80 \\
\hline Acenaphtene & 0 & 0 & 0 & 0 & 0 & 0 & 0 & 0 & 29 & 17 & 0 & 44 \\
\hline Acenaphtylene & 0 & 0 & 0 & 0 & 0 & 0 & 0 & 0 & 0 & 0 & 0 & 0 \\
\hline Anthracene & 0 & 0 & 0 & 0 & 0 & 0 & 0 & 0 & 15 & 15 & 0 & 43 \\
\hline Benzo(a)anthracene & 0 & 0 & 14 & 0 & 14 & 26 & 0 & 0 & 0 & 38 & 0 & 43 \\
\hline Benzo(a)pyrene & 0 & 0 & 0 & 0 & 0 & 5 & 0 & 0 & 0 & 0 & 0 & 40 \\
\hline Benzo(b)flouranthene & 0 & 0 & 0 & 0 & 0 & 0 & 0 & 0 & 0 & 0 & 0 & 0 \\
\hline Benzo(k)fluoranthene & 25 & 33 & 25 & 13 & 8 & 0 & 17 & 42 & 69 & 54 & 0 & 78 \\
\hline Benzo(ghi)perylene & 3 & 15 & 23 & 0 & 15 & 41 & 0 & 15 & 16 & 32 & 0 & 47 \\
\hline Chrysene & 0 & 0 & 19 & 0 & 23 & 32 & 0 & 0 & 0 & 40 & 0 & 50 \\
\hline Dibenzo(a,h)anthracene & 0 & 0 & 0 & 0 & 0 & 0 & 0 & 0 & 28 & 15 & 0 & 50 \\
\hline Fluoranthene & 29 & 35 & 35 & 12 & 35 & 35 & 12 & 24 & 0 & 13 & 0 & 19 \\
\hline Fluorene & 0 & 0 & 0 & 0 & 0 & 0 & 0 & 0 & 33 & 22 & 0 & 48 \\
\hline Indeno(1,2,3-cd)pyrene & 0 & 0 & 0 & 0 & 0 & 0 & 0 & 15 & 59 & 50 & 0 & 65 \\
\hline Naphtalene & 0 & 0 & 0 & 0 & 0 & 0 & 0 & 0 & 45 & 39 & 0 & 50 \\
\hline Phenanthrene & 0 & 0 & 0 & 0 & 0 & 0 & 0 & 5 & 25 & 23 & 0 & 30 \\
\hline Pyrene & 8 & 15 & 15 & 0 & 15 & 23 & 0 & 0 & 0 & 0 & 0 & 11 \\
\hline $\mathrm{PAH} 16$ & 0 & 0 & 4 & 0 & 4 & 16 & 0 & 0 & 3 & 18 & 0 & 34 \\
\hline PCB7 & 51 & 51 & 62 & 51 & 47 & 51 & 53 & 20 & 15 & 43 & 20 & 20 \\
\hline TBT & 0 & 0 & 0 & 46 & 9 & 0 & 25 & 49 & 12 & 59 & 0 & 80 \\
\hline
\end{tabular}

The removal efficiencies of all pollutants appear to be higher for the Sisimiut compared to the Hammerfest sediment. To test this, PLS models of heavy metals, PAH, PCB and TBT were calculated for the experiments in design 1 (table 1 ) resulting in good model correlations (R2Y, 0.90-0.99). Low Q2 values (0.20-0.47) may be due to few experiments relative to the number of variables and/or too large experimental domain. Evaluation of the models nonetheless has strong indicative values. The VIP plots of the PLS models (figure 2) reveal that the sediment is amongst the most influential variables for the removal of pollutants during EDR. This implies that for all pollutants, sediments should be modelled separately for assessing other trends. 


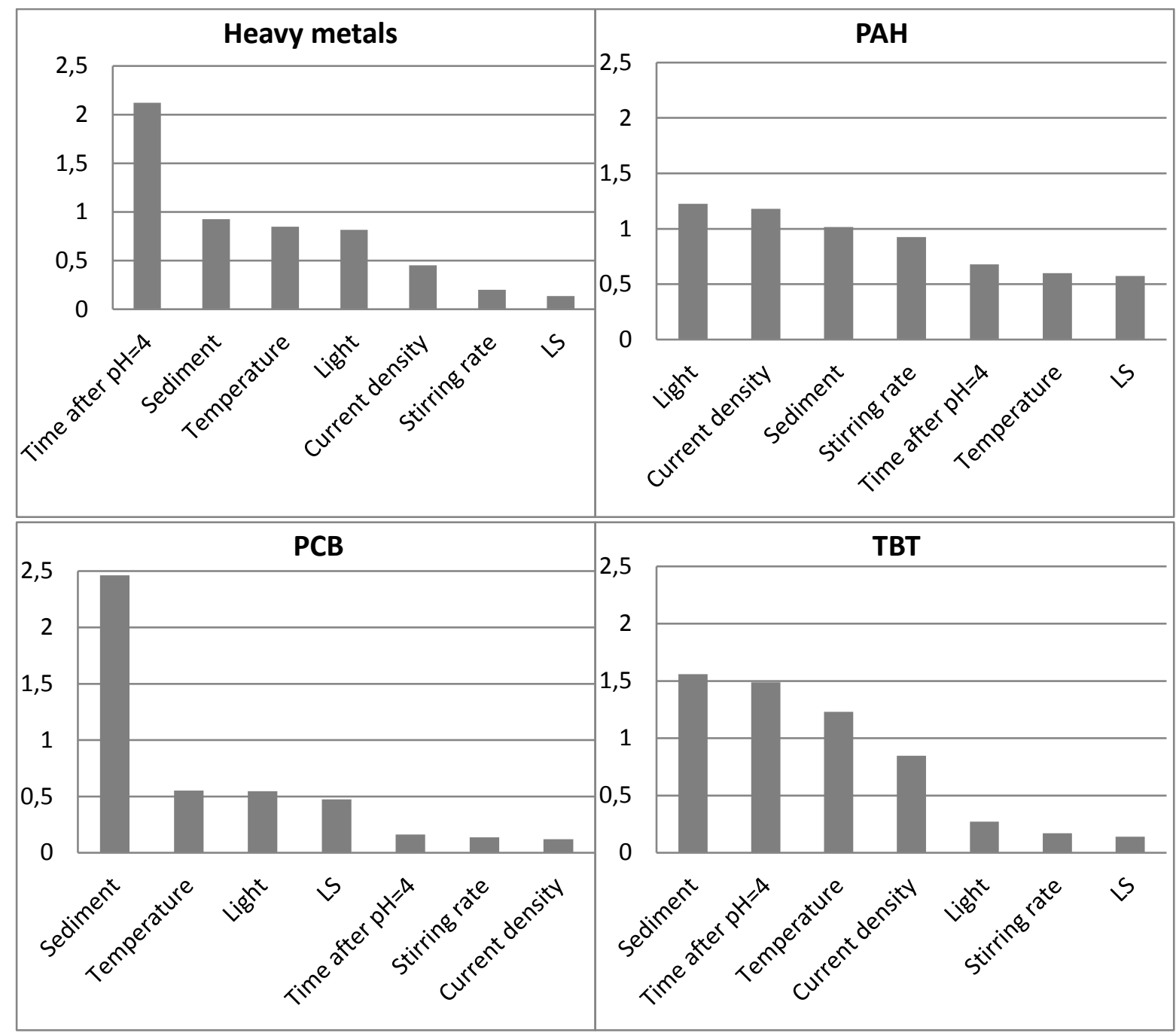

Figure 2: VIP plots of the PLS models for heavy metals, PAH, PCB and TBT in Design 1 (table 1). Variables with the highest VIP values are most influential in model correlations.

\subsection{Variable importance for heavy metals}

The removal efficiencies of $\mathrm{Zn}$ in this study are comparable to previously reported values, the removal efficiencies of $\mathrm{Pb}$ and $\mathrm{Cu}$ especially in the Hammerfest sediment, are however low compared to those previously reported, operating within similar experimental domains (Kirkelund et al., 2009, 2010; Nystroem et al., 2005a, b; Nystrøm et al., 2005; Ottosen et al., 2007; Pedersen et al., 2015c; Pedersen et al., 2015e; Pedersen et al., 2015f). This indicates that $\mathrm{Cu}$ and $\mathrm{Pb}$ are bound in less available fractions in the sediment, which may be related to the high content of organic matter in both sediments. A comparison between the desorbed fractions of $\mathrm{Cu}$ and $\mathrm{Pb}$ at the end of the EDR experiments and $\mathrm{pH}$ dependent desorption tests of the two sediments (figure 3 ) reveals that the removal efficiencies are within the desorption curves. In order to achieve higher removal efficiencies of $\mathrm{Cu}$ and $\mathrm{Pb}$ in the Hammerfest sediment, the desorption curves indicate that the $\mathrm{pH}$ should be below 1.5, whereas for the Sisimiut sediment, high removal efficiencies are observed at $\mathrm{pH} 2$. 

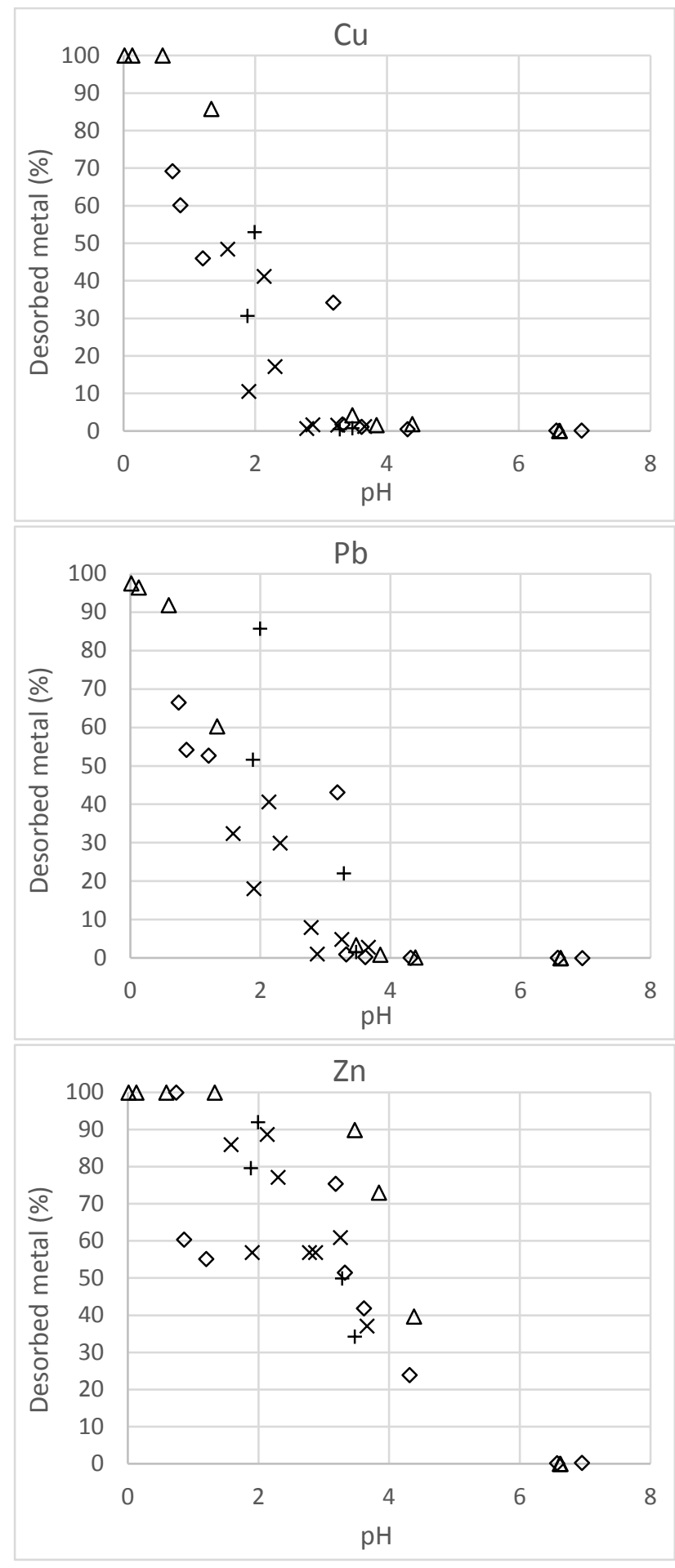
$\diamond$ HAM desorption test
$\Delta$ SIS desorption test
$\times$ HAM experiments
+SIS experiments

Figure 3: Desorption tests of $\mathrm{Cu}, \mathrm{Pb}$ and $\mathrm{Zn}$ compared to desorbed fractions of the EDR experiments.

PLS models were calculated for each of the three heavy metals for the Hammerfest sediment (R2Y 0.87-0.97; $\mathrm{Q} 2$ 0.1-0.4). The model for $\mathrm{Pb}$ was unstable ( $\mathrm{Q} 20.1$ ); so caution should be exercised when evaluating this model. As deduced from the VIP plots of the three models (figure 4), variable importance varies between the three heavy metals. Temperature being important for $\mathrm{Cu}$ and $\mathrm{Zn}$ 
while having lower impact on $\mathrm{Pb}$, but still being significant. The influence of temperature on the acidification in the EDR experiments was assessed by calculating a PLS model of the experimental variables and $\mathrm{pH}$ (R2Y 0.99; Q2 0.4) and was found to be insignificant. The influence of temperature on the electrodialytic removal of the heavy metals was hence assessed as being related to how the metals are bound in the sediment and metal speciation, in line with previous studies in which temperature was found to influence metal partitioning in suspended particulates and speciation in water (Byrne et al., 1988; Warren and Zimmerman, 1994).

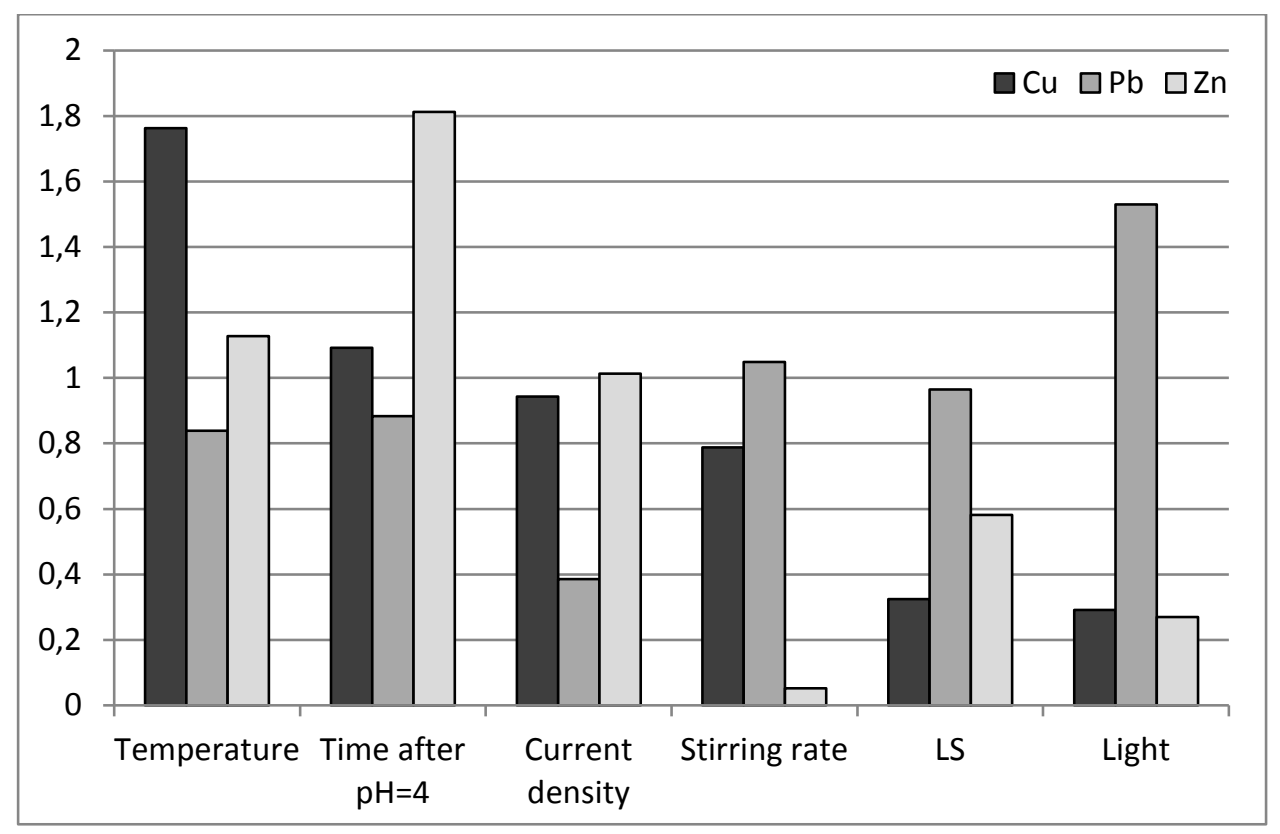

Figure 4: VIP plots for each of the PLS model of $\mathrm{Cu}, \mathrm{Pb}$ and $\mathrm{Zn}$ in Design 2, respectively. High VIP values indicate high influence on the final concentrations of the given heavy metal.

Time after acidification was significant for the three heavy metals in line with previous findings (Kirkelund et al., 2009, 2010; Nystroem et al., 2005a, b; Nystrøm et al., 2005; Ottosen et al., 2007; Pedersen et al., 2015c; Pedersen et al., 2015e; Pedersen et al., 2015f). The difference in importance of stirring rate for metals is likely related to binding in the sediment. Previous studies also found that the stirring rate was relatively more important for $\mathrm{Cu}$ and $\mathrm{Pb}$ attributed to higher amounts bound to the oxidisable fractions of the sediments (Kirkelund et al., 2009, 2010; Pedersen et al., 2015c). The relatively high influence of $\mathrm{L} / \mathrm{S}$ ratio on the removal of $\mathrm{Pb}$ and $\mathrm{Zn}$ could be related to elements found in the exchangeable fractions. The high influence of light on $\mathrm{Pb}$ removal was not found in previous studies (Pedersen et al., 2015c; Pedersen et al., 2015e) of other sediments and due to the unstable PLS model for $\mathrm{Pb}$, care should be taken in making conclusive assumptions for the Hammerfest sediment.

\subsection{Variable importance for TBT removal}

Higher removal efficiencies of TBT were observed in the Sisimiut sediment compared to the Hammerfest sediment, which could be related to the difference in the content of organic matter in the two sediments. TBT has high affinity to organic matter and is more strongly bound to organic matter than to clay minerals (Du et al., 2014), consequently resulting in lower removal efficiencies in the Hammerfest sediment. 
A PLS model of the final concentrations of TBT in the Hammerfest sediment (R2Y 0.89; Q2 0.44) revealed that the most important variables for the removal/degradation were temperature, stirring rate and light (figure 5). Temperature has previously been shown to affect degradation of TBT (Kotrikla, 2009) and may be related to adsorption of TBT and/or catabolically active microorganisms degrading TBT. The stirring rate possibly increases bioavailability and a high stirring rate may in addition ensure more uniform acidification of the sediment hence influencing desorption of TBT from the sediment, which increases with decreasing pH (Du et al., 2014). The high influence of light is in line with a recent study revealing that photolysis increases the degradation of TBT (Brosillon et al., 2014). The relatively low influence of time after acidification may indicate that acidification inhibits microbial communities hence limiting the possibilities of achieving higher removal efficiencies of TBT.

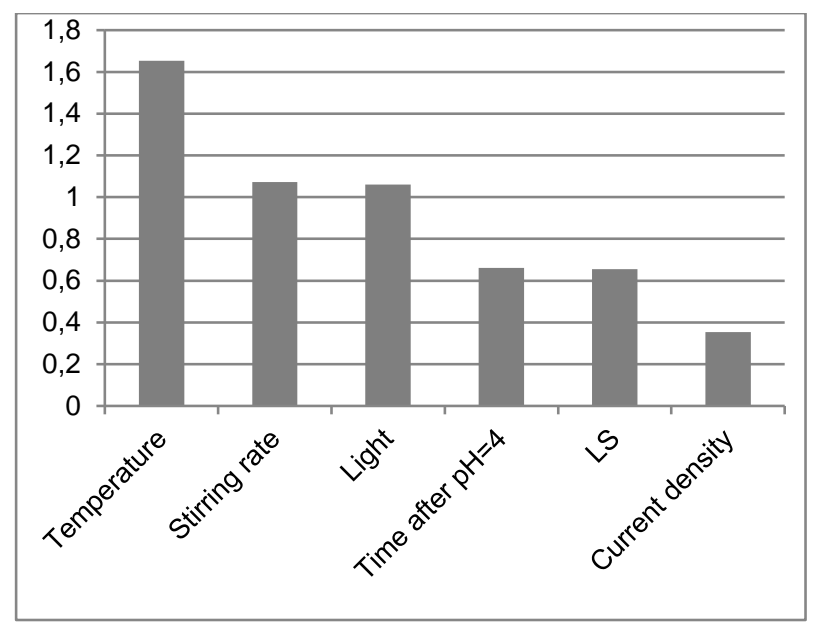

Figure 5: VIP plot for the PLS model of TBT in Design 2 (table 1). Variables with high VIP values have the highest influence on the removal of TBT.

\subsection{Variable importance for removal of PAH}

In a recent study, it was found that PAH pollution in the harbours of Hammerfest and Sisimiut was mostly related to pyrogenic sources from mainly biomass combustion (Pedersen et al., 2015b). Besides the diffuse distribution of PAH in the harbour, the sampling in Hammerfest was done close to a sewage discharge point, accordingly a larger part of the source may be related to urban activities other than road run-off and snow melting, bound mainly in the organic fraction of the sediment. The higher removal efficiencies in Sisimiut may hence be related to differences in binding to organic matter compared to the Hammerfest sediment.

Removal efficiencies were observed to be different depending on the PAH components. In Hammerfest the total removal of PAH components containing 2-3 aromatic rings was $0-25 \%$; the removal of components containing 4 aromatic rings was $0-20 \%$ and removal of components containing 5-6 aromatic rings was 0-6\%. The same trend of decreasing removal of PAH with increasing content of aromatic rings was observed for the Sisimiut sediment. To assess whether the experimental settings had an influence on the distribution of the PAH components in the sediments, PCA models of the PAH components containing 2-3; 4 and 5-6 aromatic rings were made. The plots explained 0.89-0.98 of the variation in PAH composition and generally revealed clustering of experiments according to sediment used (figure 6). This may indicate similar degradation patterns for the PAHs. There are however different trends in the variation of the PAH composition before and 
after experiments for the three PAH groups. For the compounds containing 2-3 aromatic rings, the experiments are, with a few exceptions (no. 5, 7 and 11) located adjacent to the original sediment (HAM, SIS) indicating similar distribution before and after experiments. For the PAH with 4-6 rings the PCA plot reveals a difference in distribution compared to the original sediment; the Sisimiut sediment are however, with the exception of experiment no. 5 clustered (no. 2, 3 and 8) indicating similar degradation patterns. In experiment no. 5, final concentrations for some of the PAH components were higher than the initial concentrations, which may be related to increased availability during the experiment resulting in a different distribution in components; accordingly experiment 5 is not located close to SIS in the figure.
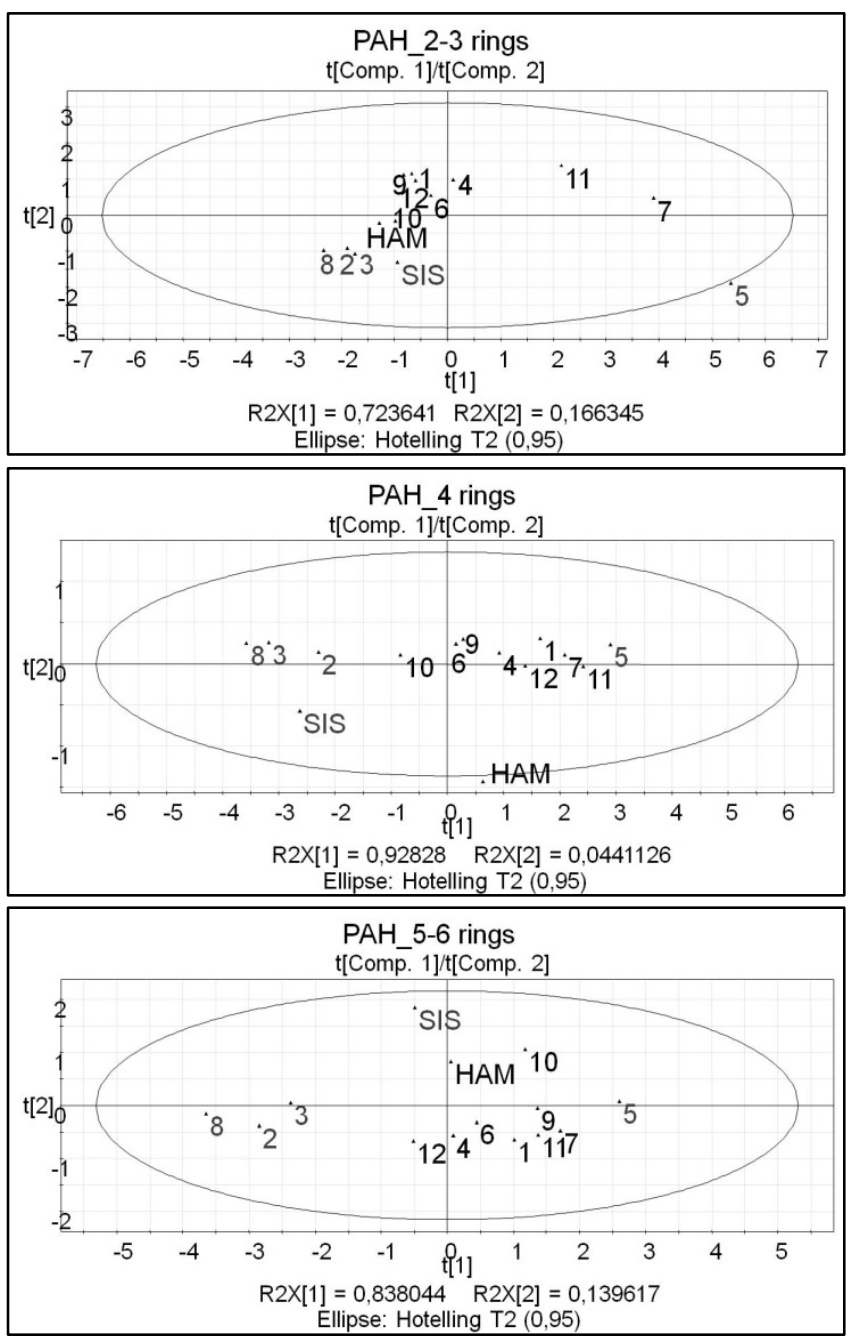

Figure 6: PCA plots of distribution of PAH components with 2-3; 4 and 5-6 aromatic rings before and after EDR experiments. Sediment from Sisimiut was used in experiments 2, 3, 5 and 8; sediment from Hammerfest was used in experiments 1, 4, 6, 7 and 9-12.

PLS models were calculated for the sum of PAH as well as for PAH components containing 2-3; 4 and 5-6 aromatic rings (R2Y 0.88-0.96; Q2 0.30-0.45). Variable importance plots for the four models illustrate differences in variable importance depending on PAH components (figure 7). Light is among the most important variables for all of the PAH components. Light has previously been shown to influence the degradation of PAH in soil, the influence decreasing with depth of the soil (Matsuzawa 
et al., 2001); the comparative influence of photo- and biodegradation of PAH has however not been established.

The VIP plots combined with coefficient contribution to the models imply that maintaining a low stirring rate is important for the removal of 2-4 aromatic rings, which may be related to high stirring rates inhibiting microbial activity in the acidified sediment. Stirring of the sediment increases the oxidation of organic matter and PAHs, accordingly the observed influence of stirring on all PAH's also indicates a strong binding of PAH to the sediment. It has previously been established that the main source of PAH pollution in Hammerfest harbour is combustion of fossil fuels and biomass (Pedersen et al., 2015b) indicating that PAH to a large degree is bound to carbonaceous particles. Strong sorption between carbonaceous particles and PAH has previously been observed, making the availability for desorption and/or degradation low (Ghosh et al., 2003; Huang et al., 2003; Reid et al., 2000).

Current density and L/S ratio have moderate to high influence on the removal of all PAH components and model coefficients imply low values of both variables increase removals. This is probably related to the rate of acidification of the sediment suspension, which is faster at high current densities and $\mathrm{L} / \mathrm{S}$ ratios. Inhibition of microbial communities and subsequent reduced degradation of persistent organic pollutants due to changes in $\mathrm{pH}$ of soil/sediments has previously been established (Gill et al., 2014; Lohner et al., 2009; Wick, 2009). This is further supported by time after acidification not significantly influencing the removal of any of the PAH components during EDR. According to the VIP plots, temperature does not affect the removal of PAH components to the same degree as other parameters. This is in line with a previous study, in which temperature did not influence the electrokinetic removal of phenanthrene, albeit operating at higher temperatures $\left(25-35^{\circ} \mathrm{C}\right)$ (NiquiArroyo et al., 2006). 


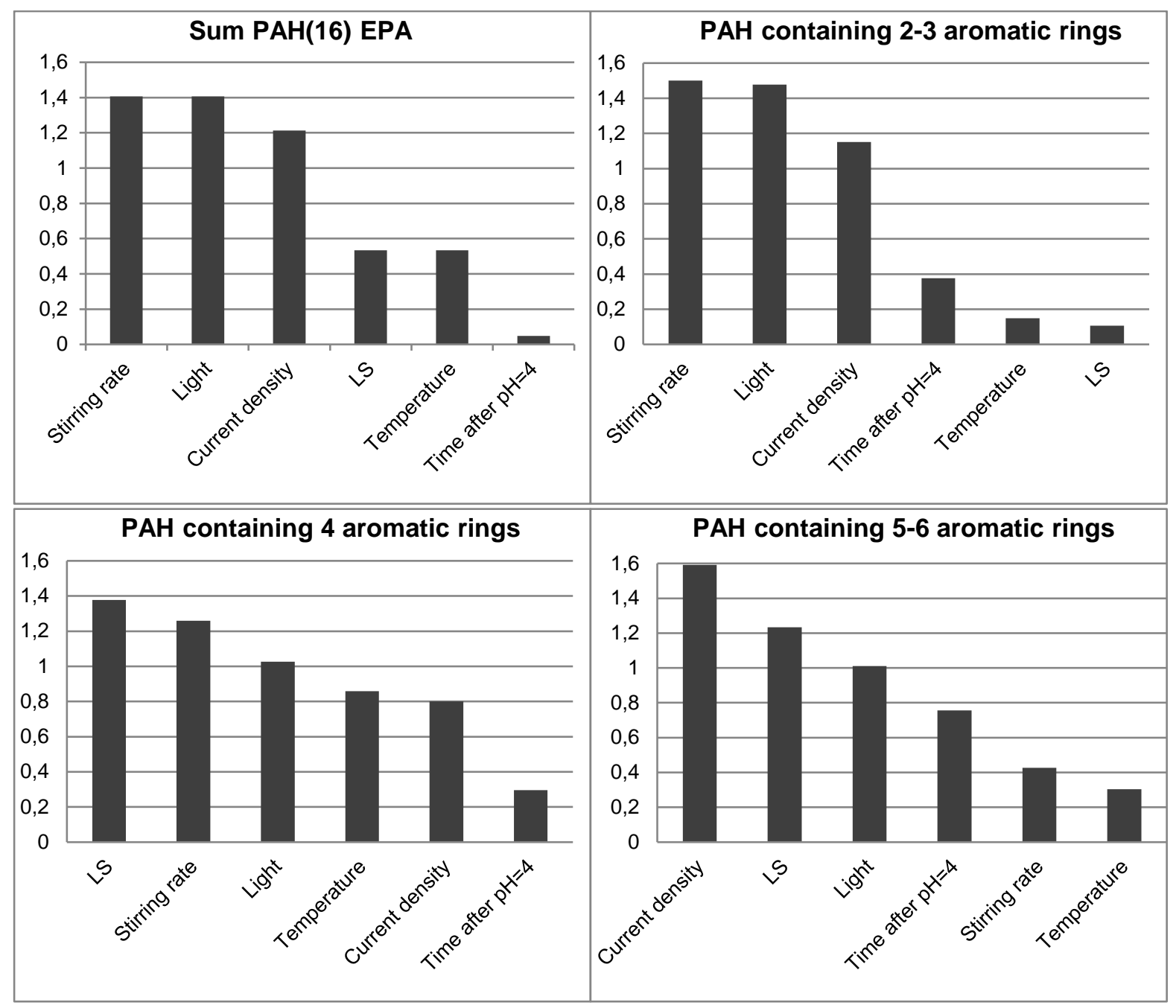

Figure 7: VIP plots of PAH (sum), PAHs containing 2-3 aromatic rings, 4 aromatic rings and 5-6 aromatic rings. Variables with high VIP values have the highest influence on the removal of PAH components during EDR.

\subsection{Variable importance for the removal of $P C B$}

The removal efficiency of the total amount of the seven PCB congeners were higher for the Hammerfest sediment with highest removal efficiencies observed for congeners containing 6-7 chlorine (PCB138, PCB153, PCB180). The relatively lower removal of congeners containing 3-5 chlorine (PCB28, PCB52, PCB101, PCB118) may be due to dechlorination of higher chlorinated congeners, as observed in other remediation studies (Gomes et al., 2014; Tang and Myers, 2002). The same trend was not observed for the Sisimiut sediment for which, relatively higher removal was observed for the congeners containing 3-5 chlorine (PCB28, PCB52, PCB101, PCB118), also in comparison to the Hammerfest sediment, suggesting comparatively lower dechlorination of higher chlorinated congeners. The difference in removal efficiencies of the congeners may be related to differences in composition of the congeners, difference in binding to organic matter/clay particles and/or microbial communities in the sediments. The initial PCB7 concentration of the Hammerfest sediment, for instance, consisted of $20 \%$ lower chlorinated congeners; in comparison, this fraction was initially $60 \%$ for the Sisimiut sediment.

A PCA plot explaining $83 \%$ of the variation in the composition of congeners before and after the EDR experiments (figure 8) revealed clustering of the experiments according to sediment used. In 
addition, the plot illustrates a difference in composition of PCB congeners before and after experiments, the clustering however indicating similar degradation patterns for each of the sediments. A PLS model of the congener concentrations and the total PCB concentration (R2Y 0.99; Q2 0.89) showed similar variation for each of the congeners PCB101, PCB138, PCB153 and PCB180 and the total PCB concentration.

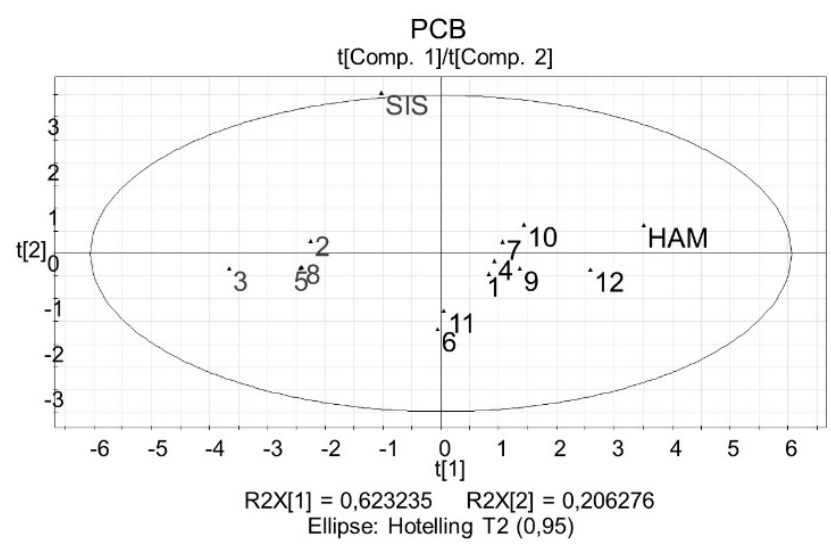

Figure 8: PCA plot of initial and final concentrations of 7 PCB congeners in the EDR experiments.

A PLS model to assess variable importance for removal of PCB was calculated (R2Y 0.92; Q2 0.24) for the Hammerfest sediment and the VIP plot showed variable importance in the order stirring rate > light $>$ temperature $>>$ time after $\mathrm{pH} 4>$ current density $>\mathrm{L} / \mathrm{S}$ ratio (figure 9 ). Model coefficients revealed that operating at low temperatures, high stirring rates and light increased the removal of PCB in the EDR experiments. It has previously been established that dechlorination of PCB during EDR/EKR is higher at low $\mathrm{pH}$ levels $(<\mathrm{pH} 5)$ due to presence of $\mathrm{H}^{+}$(Gomes et al., 2014; Wang et al., 2012). Since pH was below 4 in the experimental domain applied in this study, the high influence of stirring rate may be related to increasing and more uniform distribution of protons in the sediment suspension. The low influence of current density indicates that increasing proton concentrations in the sediment suspension does not necessarily lead to more dechlorination of the PCB congeners.

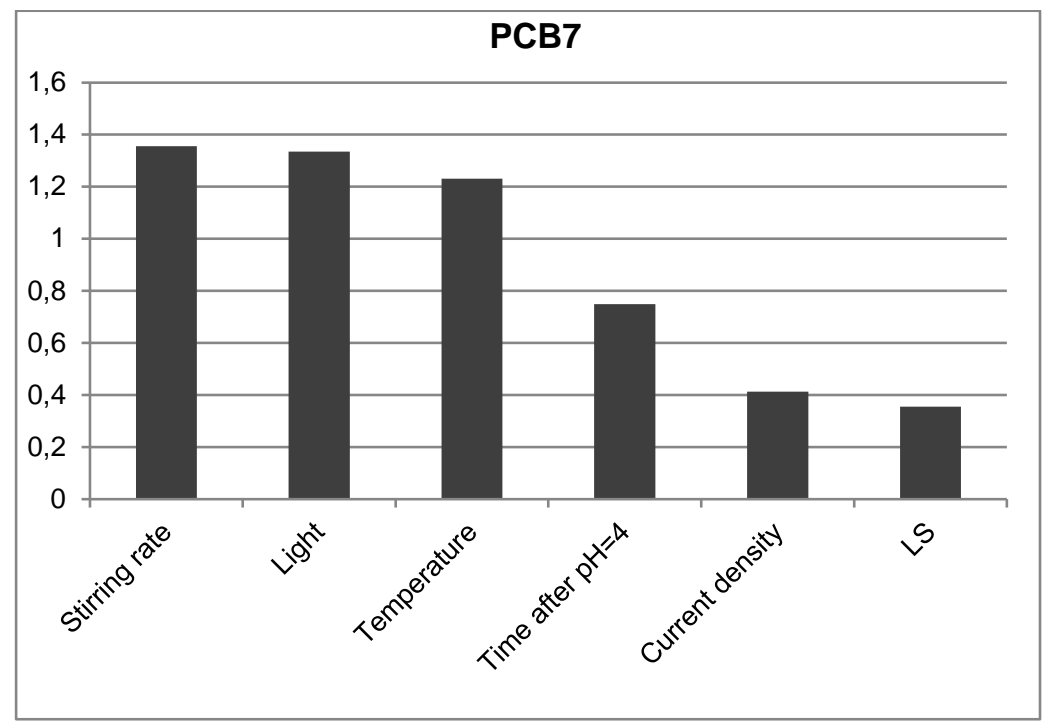

Figure 9: VIP plot for the sum of PCB congeners in Design 2 (table 1). Variables with high VIP values have the highest influence on the removal of PCB during EDR. 
Previous studies found that sunlight has low-moderate influence on degradation of PCBs, the effect decreasing with soil depth (Fan et al., 2014; Tang and Myers, 2002). The stirring of the sediment suspension in this study increased the exposure to light and the experiments were in addition conducted in a period where the sun did not set. The increased removal of PCB at low temperature has not previously been reported. Although thermal degradation $\left(200-400^{\circ} \mathrm{C}\right)$ of PCB is an established soil remediation method (Gomes et al., 2013), the influence of temperature in similar ranges to this study has not been investigated.

The removal efficiencies along with the variable importance results for $\mathrm{PCB}$ suggests different binding patterns than for PAH, since PAH and PCB have been reported to have similar sorption/desorption to carbonaceous particles (Lohmann et al., 2005; Zimmerman et al., 2004). The sources of PCB were diffuse (Pedersen et al., 2015a) and the results from this study suggests that PCB is bound to different particles in the sediment and not mainly to carbonaceous particles as was the case for PAH.

\section{Conclusions}

\subsection{Implications for EDR in cold/dark environment}

Light and temperature had different influence on the removal efficiencies depending on the given pollutant. In the Hammerfest sediment, light was found to significantly increase the removal of $\mathrm{Pb}$, TBT, PAH and PCB. It is worth mentioning that the experiments were conducted in a period of midnight sun supplying full exposure to light. In addition, stirring of the sediment ensured more uniform exposure to light. The high impact of light indicates that photolysis was one of the dominant processes for the degradation of TBT, PAH and PCB during EDR in the studied experimental domain. Since the influence of light on removal of $\mathrm{Pb}$ has not been observed in previous studies and due to the poor PLS model, further investigations of the influence of light on $\mathrm{Pb}$ binding in sediments with high content of organic matter should be pursued.

Temperature had a high influence on the removal of heavy metals, TBT and PCB from the Hammerfest sediment. For heavy metals and TBT it was suggested that this may be related to increasing desorption and possibly increased oxidation of the sediment with increasing temperature. In contrast to this, PCB removal was more efficient at low temperatures, which may be related to the naturally occurring PCB degrading microbial communities not being adapted to higher temperatures; it however appears of interest to further investigate this. Ensuring simultaneous removal at either low or high temperatures would require longer remediation time.

\subsection{Implications of acidification on the remediation}

The importance of achieving low $\mathrm{pH}(<4)$ in order to ensure significant removal of heavy metals from sediments was confirmed in this study. The acidified sediment suspension also appeared to have a positive influence on the removal of TBT and PCB attributed to chemical processes in the sediment. This was supported by the high influence of stirring rate ensuring increased availability of protons. Protons were important for desorption of TBT bound in the exchangeable fraction of the sediment and in addition it was suggested that protons may accelerate dechlorination of PCB.

The acidification of the sediment suspension appeared to have a negative effect on the degradation of PAH attributed to the low $\mathrm{pH}$ levels inhibiting the PAH degrading microbial communities in the sediment. Hence processes related to degradation of PAH in the sediments during EDR are assessed 
as being solely related to photolysis and bioremediation and due to the inhibition of the latter, photolysis was the main degradation process in the sediment. Based on the experiments it was not possible to assess whether the low $\mathrm{pH}$ values inhibited potential bioremediation of PCB and TBT.

\subsection{Optimisation}

Stirring was shown to improve the efficiency of remediation both in regards to removal of pollutants and energy consumption. This means that in the field, EDR would be performed ex-situ, entailing the implementation of an EDR unit at a given site. In order to assess the environmental benefits of applying EDR, including energy consumption for electricity and stirring, compared to the environmental impacts of the method should be evaluated, e.g. in a life cycle analysis. This would in addition provide a foundation for comparing EDR with other remediation technologies.

Removal efficiencies were generally higher in the Sisimiut than the Hammerfest sediment attributed to how pollutants were bound in the sediment and the higher content of organic matter in the Hammerfest sediment. Optimisation of EDR would besides sediment properties, take into regard seasonal conditions and the site-specific remediation objectives; i.e. desired final concentrations of the different pollutants. In Sisimiut, the background levels for $\mathrm{Pb}$ and $\mathrm{Zn}$ were met; while in Hammerfest the only pollutant equivalent to background values was $\mathrm{Zn}$. Increasing the remediation time compared to the experimental domain in this study would be expected to increase removal efficiencies of $\mathrm{Cu}, \mathrm{Pb}$ and $\mathrm{Zn}$ and possibly also TBT and PCB. Significantly increasing the removal efficiencies of PAH and PCB would entail enhancing the natural degradation, which may be achieved by adding surfactants or bacteria (e.g adding acid resistant bacteria (Dore et al., 2003)) to the sediment suspension during EDR.

This study illustrated how multivariate analysis can be used to identify dominating removal processes during EDR and can hence be used for future optimisation of the simultaneous removal of heavy metals, TBT, PAH and PCB.

\section{Acknowledgements}

The Northern Environmental Waste Management (EWMA) project, which is funded by the Research Council of Norway through NORDSATSNING (grant number 195160) and Eni Norge AS, is acknowledged for funding. Hammerfest municipality is acknowledged for providing boat and assistance in sampling of sediments in Hammerfest. Tore Lejon and Kristine B. Pedersen acknowledge The Arctic Technology Centre at DTU for funding the trip to Greenland and the technical staff, especially Sabrina Hviid, Louise Gammeltoft and Ebba Schnell is acknowledged for assistance with sampling and sediment analyses.

\section{References}

Acar, Y.B., Alshawabkeh, A.N., 1993. Principles of electrokinetic remediation. Environmental Science \& Technology 27, 2638-2647.

Agency, D.E.P., 2005. Vejledning om dumpning af optaget havbundmateriale - klapning. Vejledning fra Miljøstyrelsen nr. 8 2005, in: Agency, T.D.E.P. (Ed.). The Danish Environmental Protection Agency, Copenhagen, Denmark.

Agency, U.E.P., 2016. American sediment quality guidelines (region 3). US EPA, USA. 
Agency), N.P.C.A.n.N.E., 2007. Veileder for klassifisering av miljøkvalitet i fjorder og kystfarvann. Revidering av klassifisering av metaller og organiske miljøgifter i vann og sedimenter. . Norwegian Pollution Control Authority, Oslo, Norway.

Arevalo, E., Keller, A., Stichnothe, H., Calmano, W., 2004. Optimisation of the Operation of an Electrochemical Process To Treat TBT-contaminated Sediments on a Pilot Scale. Acta hydrochimica et hydrobiologica 32, 401-410.

Brosillon, S., Bancon-Montigny, C., Mendret, J., 2014. Study of photocatalytic degradation of tributyltin, dibutylin and monobutyltin in water and marine sediments. Chemosphere 109, 173-179. Byrne, R.H., Kump, L.R., Cantrell, K.J., 1988. The influence of temperature and pH on trace metal speciation in seawater. Marine Chemistry 25, 163-181.

Carlson, R., Carlson, J.E., 2005a. Chapter 16 Principal properties, in: Rolf, C., Johan, E.C. (Eds.), Data Handling in Science and Technology. Elsevier, pp. 351-401.

Carlson, R., Carlson, J.E., 2005b. Chapter 18 Quantitative relations: Observed responses and experimental variations, in: Rolf, C., Johan, E.C. (Eds.), Data Handling in Science and Technology. Elsevier, pp. 425-469.

Carlson, R., Carlson, J.E., 2005c. Chapter 20 Optimization when there are several responses variables, in: Rolf, C., Johan, E.C. (Eds.), Data Handling in Science and Technology. Elsevier, pp. 489-507. CCME, C.C.o.M.o.t.E., 2016. Canadian Environmental Quality Guidelines. CCME, Canada. Chapman, P.M., Wang, F., Janssen, C., Persoone, G., Allen, H.E., 1998. Ecotoxicology of metals in aquatic sediments: binding and release, bioavailability, risk assessment, and remediation. Canadian Journal of Fisheries and Aquatic Sciences 55, 2221-2243.

Colacicco, A., De Gioannis, G., Muntoni, A., Pettinao, E., Polettini, A., Pomi, R., 2010. Enhanced electrokinetic treatment of marine sediments contaminated by heavy metals and PAHs. Chemosphere 81, 46-56.

Commission, O., 2008. Atmospheric deposition of selected heavy metals and persistent organic pollutants to the OSPAR Maritime Area (1990-2005) 1ed, Moscow.

Commission, O., 2009. CEMP assessment report: 2008/2009 Assessment of trends and concentrations of selected hazardous substances in sediments and biota, London, UK. De Luca, G., Furesi, A., Leardi, R., Micera, G., Panzanelli, A., Costantina Piu, P., Sanna, G., 2004. Polycyclic aromatic hydrocarbons assessment in the sediments of the Porto Torres Harbor (Northern Sardinia, Italy). Marine Chemistry 86, 15-32.

Dore, S., Clancy, Q., Rylee, S., Kulpa Jr, C., 2003. Naphthalene-utilizing and mercury-resistant bacteria isolated from an acidic environment. Applied microbiology and biotechnology 63, 194-199.

Du, J., Chadalavada, S., Chen, Z., Naidu, R., 2014. Environmental remediation techniques of tributyltin contamination in soil and water: A review. Chemical Engineering Journal 235, 141-150.

Ebbers, B., Ottosen, L.M., Jensen, P.E., 2015. Comparison of two different electrodialytic cells for separation of phosphorus and heavy metals from sewage sludge ash. Chemosphere 125, 122-129. Fan, G., Cang, L., Fang, G., Zhou, D., 2014. Surfactant and oxidant enhanced electrokinetic remediation of a PCBs polluted soil. Separation and Purification Technology 123, 106-113. Ghosh, U., Zimmerman, J.R., Luthy, R.G., 2003. PCB and PAH speciation among particle types in contaminated harbor sediments and effects on PAH bioavailability. Environmental science \& technology 37, 2209-2217.

Gill, R.T., Harbottle, M.J., Smith, J.W.N., Thornton, S.F., 2014. Electrokinetic-enhanced bioremediation of organic contaminants: A review of processes and environmental applications. Chemosphere 107, 31-42.

Gomes, H.I., Dias-Ferreira, C., Ottosen, L.M., Ribeiro, A.B., 2014. Electrodialytic remediation of polychlorinated biphenyls contaminated soil with iron nanoparticles and two different surfactants. Journal of Colloid and Interface Science 433, 189-195.

Gomes, H.I., Dias-Ferreira, C., Ribeiro, A.B., 2013. Overview of in situ and ex situ remediation technologies for PCB-contaminated soils and sediments and obstacles for full-scale application. Science of The Total Environment 445-446, 237-260. 
Huang, W., Peng, P.a., Yu, Z., Fu, J., 2003. Effects of organic matter heterogeneity on sorption and desorption of organic contaminants by soils and sediments. Applied Geochemistry 18, 955-972. Hung, H., Kallenborn, R., Breivik, K., Su, Y., Brorström-Lundén, E., Olafsdottir, K., Thorlacius, J.M., Leppänen, S., Bossi, R., Skov, H., Manø, S., Patton, G.W., Stern, G., Sverko, E., Fellin, P., 2010. Atmospheric monitoring of organic pollutants in the Arctic under the Arctic Monitoring and Assessment Programme (AMAP): 1993-2006. Science of The Total Environment 408, 2854-2873. Kirkelund, G.M., Ottosen, L.M., Villumsen, A., 2009. Electrodialytic remediation of harbour sediment in suspension-Evaluation of effects induced by changes in stirring velocity and current density on heavy metal removal and $\mathrm{pH}$. Journal of Hazardous Materials 169, 685-690.

Kirkelund, G.M., Ottosen, L.M., Villumsen, A., 2010. Investigations of $\mathrm{Cu}, \mathrm{Pb}$ and $\mathrm{Zn}$ partitioning by sequential extraction in harbour sediments after electrodialytic remediation. Chemosphere $79,997-$ 1002.

Kotrikla, A., 2009. Environmental management aspects for TBT antifouling wastes from the shipyards. Journal of Environmental Management 90, S77-S85.

Lima, A.T., Ottosen, L.M., Heister, K., Loch, J.P.G., 2012. Assessing PAH removal from clayey soil by means of electro-osmosis and electrodialysis. Science of The Total Environment 435-436, 1-6. Lohmann, R., MacFarlane, J., Gschwend, P., 2005. Importance of black carbon to sorption of native PAHs, PCBs, and PCDDs in Boston and New York harbor sediments. Environmental Science \& Technology 39, 141-148.

Lohner, S.T., Tiehm, A., Jackman, S.A., Carter, P., 2009. Coupled Electrokinetic-Bioremediation: Applied Aspects, Electrochemical Remediation Technologies for Polluted Soils, Sediments and Groundwater. John Wiley \& Sons, Inc., pp. 389-416.

Matsuzawa, S., Nasser-Ali, L., Garrigues, P., 2001. Photolytic behavior of polycyclic aromatic hydrocarbons in diesel particulate matter deposited on the ground. Environmental science \& technology 35, 3139-3143.

Mulligan, C.N., Yong, R.N., Gibbs, B.F., 2001. An evaluation of technologies for the heavy metal remediation of dredged sediments. Journal of Hazardous Materials 85, 145-163.

Niqui-Arroyo, J.-L., Bueno-Montes, M., Posada-Baquero, R., Ortega-Calvo, J.-J., 2006. Electrokinetic enhancement of phenanthrene biodegradation in creosote-polluted clay soil. Environmental Pollution 142, 326-332.

Nystroem, G.M., Ottosen, L.M., Villumsen, A., 2005a. Acidification of Harbor Sediment and Removal of Heavy Metals Induced by Water Splitting in Electrodialytic Remediation. Separation Science and Technology 40, 2245-2264.

Nystroem, G.M., Ottosen, L.M., Villumsen, A., 2005b. Electrodialytic Removal of Cu, Zn, Pb, and Cd from Harbor Sediment: Influence of Changing Experimental Conditions. Environmental Science \& Technology 39, 2906-2911.

Nystrøm, G.M., Ottosen, L.M., Villumsen, A., 2005. Test of experimental set-ups for electrodialytic removal of $\mathrm{Cu}, \mathrm{Zn}, \mathrm{Pb}$ and $\mathrm{Cd}$ from different contaminated harbour sediments. Engineering Geology 77, 349-357.

Ottosen, L.M., Christensen, I.V., Rörig-Dalgård, I., Jensen, P.E., Hansen, H.K., 2008. Utilization of electromigration in civil and environmental engineering-Processes, transport rates and matrix changes. Journal of Environmental Science and Health, Part A 43, 795-809.

Ottosen, L.M., Hansen, H.K., Hansen, C.B., 2000. Water splitting at ion-exchange membranes and potential differences in soil during electrodialytic soil remediation. Journal of Applied Electrochemistry 30, 1199-1207.

Ottosen, L.M., Hansen, H.K., Laursen, S., Villumsen, A., 1997. Electrodialytic Remediation of Soil Polluted with Copper from Wood Preservation Industry. Environmental Science \& Technology 31, 1711-1715.

Ottosen, L.M., Jensen, P.E., Kirkelund, G.M., Dias-Ferreira, C., Hansen, H.K., 2012. Electrodialytic Remediation of heavy Metal polluted Soil-treatment of water saturated or suspended soil. Chemical Engineering 28. 
Ottosen, L.M., Nystrøm, G.M., Jensen, P.E., Villumsen, A., 2007. Electrodialytic extraction of Cd and Cu from sediment from Sisimiut Harbour, Greenland. Journal of Hazardous Materials 140, 271-279. Pedersen, K., Lejon, T., Jensen, P., Ottosen, L., 2015a. Chemometric analysis for pollution source assessment of harbour sediments in arctic locations. Water Air Soil Pollut 226.

Pedersen, K., Lejon, T., Jensen, P., Ottosen, L., 2015b. Chemometric Analysis for Pollution Source Assessment of Harbour Sediments in Arctic Locations. Water Air Soil Pollut 226, 1-15.

Pedersen, K.B., Jensen, P.E., Ottosen, L.M., Lejon, T., 2015c. An optimised method for electrodialytic removal of heavy metals from harbour sediments. Electrochimica Acta 173, 432-439.

Pedersen, K.B., Kirkelund, G.M., Ottosen, L.M., Jensen, P.E., Lejon, T., 2015d. Multivariate methods for evaluating the efficiency of electrodialytic removal of heavy metals from polluted harbour sediments. Journal of Hazardous Materials 283, 712-720.

Pedersen, K.B., Lejon, T., Jensen, P.E., Ottosen, L.M., 2016a. Applying multivariate analysis as decision tool for evaluating sediment-specific remediation strategies. Chemosphere 151, 59-67.

Pedersen, K.B., Lejon, T., Jensen, P.E., Ottosen, L.M., 2016b. Degradation of oil products in a soil from a Russian Barents hot-spot during electrodialytic remediation. SpringerPlus 5, 168.

Pedersen, K.B., Lejon, T., Ottosen, L.M., Jensen, P.E., 2015e. Screening of variable importance for optimizing electrodialytic remediation of heavy metals from polluted harbour sediments.

Environmental Technology 36, 2364-2373.

Pedersen, K.B., Ottosen, L.M., Jensen, P.E., Lejon, T., 2015f. Comparison of 2-compartment, 3compartment and stack designs for electrodialytic removal of heavy metals from harbour sediments. Electrochimica Acta 181, 48-57.

Peng, J.-f., Song, Y.-h., Yuan, P., Cui, X.-y., Qiu, G.-I., 2009. The remediation of heavy metals contaminated sediment. Journal of hazardous materials 161, 633-640.

Perelo, L.W., 2010. Review: In situ and bioremediation of organic pollutants in aquatic sediments. Journal of Hazardous Materials 177, 81-89.

Programme, A.M.A., 2003. AMAP Assessment 2002: Human Health in the Arctic. Arctic Monitoring and Assessment Programme (AMAP), P.O. Box 8100 Dep, N-0032 Oslo, Norway (www.amap.no), Oslo.

Programme, A.M.A., 2005. AMAP Assessment 2002: Heavy Metals in the Arctic. Arctic Monitoring and Assessment Programme (AMAP), P.O. Box 8100 Dep, N-0032 Oslo, Norway (www.amap.no), Oslo, Norway.

Reid, B.J., Jones, K.C., Semple, K.T., 2000. Bioavailability of persistent organic pollutants in soils and sediments-a perspective on mechanisms, consequences and assessment. Environmental Pollution 108, 103-112.

Rigét, F., Bignert, A., Braune, B., Stow, J., Wilson, S., 2010. Temporal trends of legacy POPs in Arctic biota, an update. Science of The Total Environment 408, 2874-2884.

Sato, T., Todoroki, T., Shimoda, K., Terada, A., Hosomi, M., 2010. Behavior of PCDDs/PCDFs in remediation of PCBs-contaminated sediments by thermal desorption. Chemosphere 80, 184-189. Tang, N.H., Myers, T.E., 2002. PCB removal from contaminated dredged material. Chemosphere 46, 477-484.

Trygg, J., Wold, S., 2002. Orthogonal projections to latent structures (O-PLS). Journal of Chemometrics 16, 119-128.

Wang, Y., Zhou, D., Wang, Y., Wang, L., Cang, L., 2012. Automatic pH control system enhances the dechlorination of 2, 4, 4'-trichlorobiphenyl and extracted PCBs from contaminated soil by nanoscale $\mathrm{Fe} 0$ and $\mathrm{Pd} / \mathrm{Fe} 0$. Environ Sci Pollut Res 19, 448-457.

Warren, L.A., Zimmerman, A.P., 1994. The influence of temperature and $\mathrm{NaCl}$ on cadmium, copper and zinc partitioning among suspended particulate and dissolved phases in an urban river. Water Research 28, 1921-1931.

Wick, L.Y., 2009. Coupling Electrokinetics to the Bioremediation of Organic Contaminants: Principles and Fundamental Interactions, Electrochemical Remediation Technologies for Polluted Soils, Sediments and Groundwater. John Wiley \& Sons, Inc., pp. 367-387. 
Wold, S., Sjöström, M., Eriksson, L., 2001. PLS-regression: a basic tool of chemometrics.

Chemometrics and intelligent laboratory systems 58, 109-130.

Yang, G.C.C., 2009. Electrokinetic-Chemical Oxidation/Reduction, Electrochemical Remediation Technologies for Polluted Soils, Sediments and Groundwater. John Wiley \& Sons, Inc., pp. 439-471. Zimmerman, J.R., Ghosh, U., Millward, R.N., Bridges, T.S., Luthy, R.G., 2004. Addition of Carbon Sorbents to Reduce PCB and PAH Bioavailability in Marine Sediments: Physicochemical Tests.

Environmental Science \& Technology 38, 5458-5464. 